Original Research Paper

\title{
Introduksi "Bondre" Untuk Mengatasi Gagal Panen Rumput Laut Pada Cuaca Ekstrim di Pantai Jelenga Kabupaten Sumbawa Barat
}

\author{
Nunik Cokrowati ${ }^{1 *}$, Muhammad Junaidi ${ }^{1}$, Nanda Diniarti ${ }^{1}$, Andre Rachmat Scabra ${ }^{1}$, Sunaryo $^{2}$ \\ ${ }^{1}$ Program Studi Budidaya Perairan, Jurusan Perikanan dan Ilmu Kelautan, Fakultas Pertanian, Universitas \\ Mataram, Mataram, Lombok, NTB, Indonesia. \\ ${ }^{2}$ Dinas Kelautan dan Perikanan Kabupaten Sumbawa Barat, Sumbawa Barat, NTB, Indonesia.
}

https://doi.org/10.29303/jpmpi.v3i2.946

Sitasi: Cokrowati, N., Junaidi, M., Diniarti, N., Scabra, A. R \& Sunaryo. (2021). Introduksi "Bondre" Untuk Mengatasi Gagal Panen Rumput Laut Pada Cuaca Ekstrim di Pantai Jelenga Kabupaten Sumbawa Barat. Jurnal Pengabdian Magister Pendidikan IPA, 4(3)

\section{Article history}

Received: 31 Juli 2021

Revised: 2 September 2021

Accepted: 6 September 2021

*Corresponding Author: Nunik Cokrowati, Program Studi Budidaya Perairan, Jurusan Perikanan dan Ilmu Kelautan, Fakultas Pertanian Universitas Mataram, Mataram. Email: nunikcokrowati@unram.ac.id

\begin{abstract}
Abstrak: Perairan pantai Jelenga terletak di Kecamatan Jereweh Kabupaten Sumbawa Barat, merupakan lokasi budidaya rumput laut sejak tahun 2010. Kegiatan budidaya sempat terhenti karena perubahan minat masyarakat terhadap mata pencaharian dan kembali dilakukan pada tahun 2020. Permasalahan mitra kegiatan yang perlu disolusikan adalah gagal panen akibat gelombang besar. Tujuan kegiatan ini adalah untuk mengintroduksi penggunaan jaring "Bondre" pada budidaya rumput laut untuk mengatasi gagal panen akibat gelombang besar. Metode kegiatan yang digunakan adalah tutorial langsung melalui kegiatan penyuluhan dan pendampingan mengenai pembuatan, penggunaan dan manfaat jaring bondre. Hasil kegiatan adalah kegiatan penyuluhan dilakukan dengan cara memberikan penjelasan secara langsung dan memberikan contoh bondre untuk diterapkan pada musim gelombang besar. Diskusi dan pendampingan mengenai upaya peningkatan produksi rumput laut juga dilakukan. Kesimpulan kegiatan ini adalah introduksi penggunaan dan manfaat bondre telah dilakukan kepada pembudidaya rumput laut di pantai Jelenga.
\end{abstract}

Kata kunci : Kappaphycus alvarezii, budidaya, produksi, karaginan, pendapatan.

\section{Pendahuluan}

Rumput laut merupakan komoditas potensial usaha skala kecil dan menengah. Rumput laut memiliki banyak manfaat, baik melalui pengolahan sederhana yang langsung dapat dikonsumsi maupun melalui pengolahan yang lebih kompleks, seperti produk farmasi, kosmetik, dan pangan, serta produk lainnya (Priono, 2013). Produksi rumput laut yang dihasilkan di negara kita berasal dari kegiatan budidaya rumput laut. Produksi dan rumput laut di provinsi Nusa Tenggara Barat pada tahun 2019 sebanyak 896.760,37 ton (Dinas Kelautan Perikanan Provinsi NTB, 2019). Produksi rumput laut di provinsi Nusa Tenggara barat dihasilkan dari budidaya rumput laut di pulau Lombok dan Pulau Sumbawa. Lokasi budidaya tersebut antara lain
Ekas Kabupaten Lombok Timur, Seriweh Kabupaten Lombok Timur, Gerupuk Kabupaten Lombok Tengah, Kertasari Kabupaten Sumbawa Barat, Tuananga Kabupaten Sumbawa Barat, Jelenga Kabupaten Sumbawa Barat, Kaung Kabupaten Sumbawa, Dompu dan Labuan Bajo Kabupaten Bima. Jenis rumput laut yang dibudidayakan adalah Kappaphycus alvarezii, Eucheuma spinosum dan Gracillaria. Kappaphycus alvarezii merupakan jenis yang pada umumnya dibudidayakan. Metode budidaya yang digunakan adalah metode patok dasar, longline dan rakit apung. Metode budidaya yang dipilih pembudidaya ditentukan berdasarkan kondisi subtrat dan lingkungan perairan. Perairan dengan kondisi subtrat karang berpasir dan gerakan air yang 
tenang, maka metode budidaya yang digunakan adalah patok dasar misalnya di Kertasari. Perairan dengan gerakan air yang relatif tidak besar dan perairan berbentuk teluk maka menggunakan rakit apung contohnya di Ekas. Perairan yang pergerakan airnya relatif besar dan kedalaman lebih dari 7 meter maka menggunakan longline. Cokrowati et all., (2021) menerapkan metode long line pada perairan Kecamatan Buer yang memiliki karakteristik gerakan air yang relatif besar.

Budidaya rumput laut dapat dilakukan sepanjang musim dengan mempertimbangkan keberlanjutan ekosistem perairan. Hasil panen dari budidaya rumput laut dipengaruhi faktor fisik, kimia dan biologi yang ada di perairan. Diantara faktor tersebut adalah gerakan air yang besar pada musim tertentu menjadi penyebab gagalnya panen rumput laut. Rumput laut yang dibudidayakan akan patah akibat gerakan air yang besar dan hanyut. Sehingga hasil panen tidak dapat optimal. Teknologi penggunaan "Bondre" dapat digunakan untuk mensolusikan permasalahan tersebut. Bondre merupakan jaring yang berbentuk kantong memanjang dan dibuat dari tali polietilen. Ukuran bondre dapat disesuaikan dengan ukuran konstruksi budidaya. Bondre digunakan untuk wadah budidaya rumput laut pada saat musim gelombang besar. Bibit rumput laut diletakkan di dalam bondre sehingga meskipun patah maka rumput laut akan tetap berada di jaring bondre terebut. Bondre dapat diikat pada metode patok dasar, longline dan rakit apung.

Hasil penelitian Wibowo et al., (2020) menjelaskan bahwa budidaya rumput laut Kappaphycus alvarezii pada patok dasar dengan menggunakan kantong atau net bag menghasilkan pertumbuhan spesifik rumput laut terbaik yaitu sebesar 4,95 $\pm 0,70 \%$ g/hari. Syarqawi et al., (2017) menjelaskan bahwa budidaya rumput laut dengan menggunakan kantong, layak diaplikasikan untuk membantu pembudidaya rumput laut dalam meningkatkan produksinya. Ghazali et al., (2020) melakukan pendampingan pembudidaya rumput laut di teluk Ekas Lombok Timur dengan mengaplikasikan metode budidaya longline dengan bondre. Metode tersebut dapat mendukung kemandirian pembudidaya rumput laut di teluk ekas dalam menyediakan bibit rumput laut. Hasil penelitian Sulistyaningsih et al., (2018) menjelaskan bahwa budidaya rumput laut menggunakan bondre menghasilkan pertumbuhan yang lebih optimal.

Jelenga terletak di Kabupaten Sumbawa Barat, merupakan lokasi budidaya rumput laut sejak tahun 2010 namun sempat terhenti karena perubahan minat masyarakat terhadap mata pencaharian lainnya. Pada tahun 2020 mulai muncul lagi kegiatan budidaya rumput di Jelenga dan mulai terbentuk kelompok pembudidaya rumput laut yaitu Jelenga Gemilang. Permasalahan mitra saat ini yang perlu disolusikan pada budidaya rumput laut di Jelenga adalah gagal panen akibat gelombang besar. Tujuan kegiatan ini adalah untuk mengintroduksi penggunaan jaring "Bondre" pada budidaya rumput laut untuk mengatasi gagal panen akibat cuaca ekstrim. Manfaat kegiatan ini adalah pembudidaya dapat memperoleh hasil panen yang optimal sepanjang tahun tanpa mengalami gagal panen pada saat terjadi cuaca ekstrim yaitu gelombang besar. Sehingga produksi rumput laut dapat ditingkatkan dan dapat meningkatkan perekonomiam pembudidaya.

\section{Metode Kegiatan}

Kegiatan ini dilaksanakan di Pantai Desa Jelenga Kecamatan Jelenga Kabupaten Sumbawa Barat Provinsi Nusa Tenggara Barat. Metode kegiatan yang digunakan adalah penyuluhan pengenalan penggunaan jaring Bondre untuk budidaya rumput laut. Kegiatan dilakukan dengan tahapan sosia;isasi program, penyuluhan dan pendampingan. Sosialisasi Program dilakukan sejak direncanakan kegiatan yaitu diskusi dengan mitra kegiatan dan penyuluh pembudidaya rumput laut yang mengkoordinir wilayah kegiatan. Tim kegiatan mendiskusikan permasalahan apa yang sedang dihadapi pembudidaya rumput laut di Jelengah perlu segera diberikan solusi. Selanjutnya kegiatan direncanakan dan dilaksanakan. Kegiatan penyuluhan dilakukan dengan cara menyampaikan pemaparan materi mengenai teknologi penggunaan jaring bondre untuk mengatasi kerontokan rumput laut. Bondre juga diberikan kepada kelompok pembudidaya untuk diterapkan pada budidaya yang mereka lakukan. Kegiatan pendampingan kepada kelompok pembudidaya memang telah dilakukan sejak tahun 2020 sampai sekarang. 
Pendampingan terus akan dilakukan untuk mewujudkan produksi rumput laut yang kontinyu.

\section{Hasil dan Pembahasan}

Introduksi bondre untuk mengatasi gagal panen akibat kerontokan rumput laut karena cuaca ekstrim telah diberikan kepada mitra kegiatan yaitu kelompok pembudidaya rumput laut di pantai Jelengah. Introduksi dilakukan melalui kegiatan penyuluhan dengan cara menyampaikan dan mempraktekkan secara langsung penggunaan bondre. Bondre adalah jaring memanjang yang terbuat dari tali nilon yang dirajut sehingga membentuk jaring panjang. Tali nilon yang digunakan berdiameter $6 \mathrm{~mm}$ dan dapat juga menggunakan diameter $9 \mathrm{~mm}$. Panjang jaring bondre yang digunakan adalah 6 meter atau dapat disesuaikan panjang konstruksi yang digunakan untuk budidaya. Pada umumnya tali ris yang digunakan untuk metode patok dasar adalah sepanjang 6 meter. Jika tali ris yang digunakan kurang atau lebih dari 6 meter maka panjang bondre disesuaikan dengan panjang tali ris tersebut. Gambar 1 merupakan penjelasan cara pembuatan jaring bondre yang terbuat dari tali nilon.

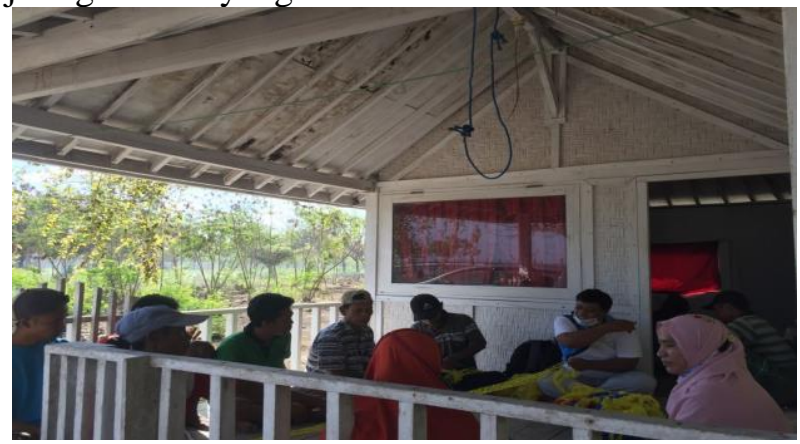

Gambar 1. Penjelasan cara pembuatan jaring Bondre

Sulystyaningsih et al (2018) menjelaskan hasil penelitiannya bahwa bondre yang diterapkan pada budidaya rumput laut di Teluk Ekas Lombok Timur, dapat membantu mengatasi permasalahan kerontokan rumput laut.

Penyuluhan dihadiri oleh anggota kelompok pembudidaya, tim kegiatan, dan penyuluh perikanan yang membawahi budidaya rumput laut di Pantai Jelengah. Materi disampaikan oleh tim kegiatan dan penyuluh perikanan. Selanjutnya dilakukan diskusi terkait budidaya rumput laut yang dilakukan di pantai Jelengah. Berikut gambar saat penyuluhan dan diskusi bersama pembudidaya rumput laut di pantai Jelengah. Gambar 2 merupakan keseluruhan anggota kelompok pembudidaya setelah mengikuti kegiatan penyuluhan.

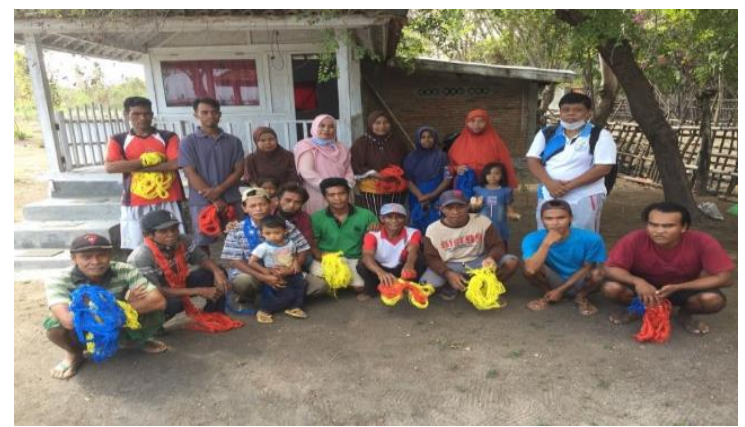

Gambar 2. Kelompok pembudidaya rumput laut

Pantai Jelenga merupakan perairan yang produktif dan memiliki nilai estetika sebagai pantai dengan pasir putih. Pada beberapa titik perairan pantai ini dapat digunakan sebagai area surfing dan kontinyu dikunjungi oleh wisatawan asing. Pantai Jelenga pada awalnya diperuntukkan untuk Pariwisata, namun seriring dengan berkembangnya alternatif pendapatan masyarakat maka sebagian wilayah perairan diperuntukkan untuk budidaya rumput laut. Budidaya rumput laut di perairan pantai Jelengah dimulai pada tahun 2020 hingga saat ini. Jenis rumput laut yang dibudiayakan adalah Kappaphycus alvarezii warna hijau dengan metode patok dasar. Berdasarkan informasi pembudidaya dan penyuuh perikanan, pertumbuhan rumput laut yang dibudidayakan di perairan pantai Jelengah ini cukup baik. Produksi yang dihasilkan rata-rata pertahun dapat bersumbangsih terhadap peningkatan pendapatan pembudidaya. Berikut adalah gambar kegiatan budidaya rumput laut yang dilakukan oleh kelompok pembudidaya mitra kegiatan ini.

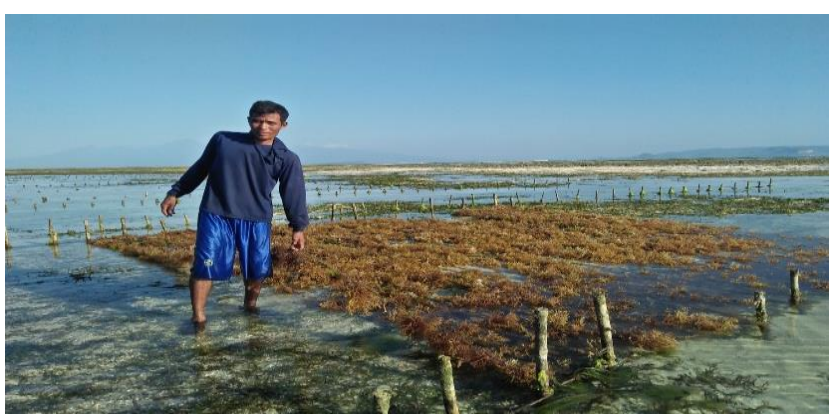

Gambar 3. Budidaya rumput laut di pantai Jelenga 
Perairan pantai Jelenga yang digunakan sebagai area budidaya rumput laut merupakan area yang disepakati bersama oleh masyarakat dan pemerintah. Perairana pantai Jelenga secara visual memiliki air yang jernih. Erwansyah et all., (2021) menjelaskan hasil penelitiannya bahwa kualitas air perairan pantai Jelenga layak sebagai area budidaya rumput laut. Produksi rumput laut yang dihasilkan akan terus meningkat jika pembudidaya terus kontinyu berbudidaya dan didukung dengan teknologi yang dapat meningkatkan produksi.

\section{Kesimpulan}

Jaring Bondre telah diintroduksi penggunaan dan kegunaannya kepada pembudidaya rumput laut di pantai Jelenga untuk mengatasi gagal panen akibat cuaca ekstrim.

\section{Saran}

Kegiatan selanjutnya yang perlu dilakukan adalah demplot budidaya rumput laut dengan menggunakan bondre dan tanpa penggunaan bondre. Hasil pertumbuhan dan hasil produksi kedua metode tersebut dapat dianalisa perbedaan hasil produksinya.

\section{Ucapan Terima Kasih}

Ucapan terimakasih disampaikan kepada Universitas Mataram yang telah mendanai kegiatan ini melalui pendanaan pengabdian kepada masyarakat PNBP Fakultas Pertanian tahun anggaran 2021.

\section{Daftar Pustaka}

Cokrowati, N., Nikmatullah, A., Sulman, E., Hardiawansyah., \& Erwansyah. 2021. Pengembangan Budidaya Rumput Laut Kappaphycus alvarezii di Perairan Kecamatan Buer Kabupaten Sumbawa. Jurnal Pengabdian Magister Pendidikan IPA, 4(2). DOI: https://doi.org/10.29303/jpmpi.v4i2.800.

Dinas Kelautan dan Perikanan Provinsi NTB. 2019. Data Produksi Rumput Laut Provinsi NUSA Tenggara Barat. DKP Provinsi NTB. Mataram.

Erwansyah, Cokrowati, N., Sunaryo. 2021. Kondisi Perairan Pantai Jelenga Sumbawa Barat sebagai Area Budidaya Rumput Laut Kappaphycus alvarezii. Jurnal Ilmu Perairan (Aquatic Science). Volume 9 No.2 (2021): 94-98. P-ISSN 1693-2862. http://dx.doi.org/10.31258/jipas.9.2.p.94-98.

Ghazali, M., Rina Kurnianingsih, Nurhayati dan Sunarpi. 2020. Pendampingan Kelompok Tani "Pasir Putih" Dalam Mewujudkan Desa Ekas Buana Sebagai Limbung Bibit Rumput Laut Nusa Tenggara Barat. Jurnal Masyarakat Mandiri. Vol. 4, No. 5, November 2020, Hal. 742-751. eISSN2614-5758. p-ISSN 2598-8158. DOI: https://doi.org/10.31764/jmm.v4i5.295 $\underline{0 .}$

Priono, Bambang. 2013. Budidaya Rumput Laut dalam Upaya Peningkatan Industrialisasi Perikanan. Media Akuakultur. Volume 8 Nomor 1.

Syarqawi, M., Sayyid, A., dan Ichsan, R.. 2017. Pengaruh Penggunaan Kantong Terhadap Pertumbuhan Rumput Laut (Eucheuma cottoni) di Perairan Kabupaten Simeulue. Jurnal Ilmiah Mahasiswa Kelautan dan Perikanan Unsyiah. Volume 2, Nomor 2: 277-285. ISSN. 2527-639.

Sulistyaningsih, N. D., Aluh, N., dan Dewi, N.S. 2018. Analysis of Using Bondre System to Cultivate Three Kinds of Seaweed Through Different Seed Weights in The Early Summer at Ekas Bay, Jerowaru, East Lombok. International Journal of Scientific and Research Publications. Volume 8. Issue 11. DOI: 10.29322/IJSRP.8.11.2018.p8343.

Wibowo, I.S., Gunawan, W.S. dan Ali, D. 2020. Metode Lepas Dasar dengan Net Bag pada Pertumbuhan Kappaphycus alvarezii, Doty ex Silva (Florideophyceae: Solieriaceae). Journal of Marine Research. Vol 9, No.1 Februari 2020, pp. 49-54. DOI : 10.14710/jmr.v9i1.25783. 